\title{
DETERMINATION EFFECTS OF SLC27A3 AND B- LACTOGLOBULIN GENE POLYMORPHISMS ON THE MILK COMPOSITION IN HAMDANI SHEEP
}

\author{
BAYRAKTAR, $M .^{1 *}-$ SHOSHIN, $O{ }^{2}$ \\ ${ }^{1}$ College of Agriculture, Animal Science, Çukurova University, Adana, Turkey \\ ${ }^{2}$ College of Veterinary, Physiology Science, Kirkuk University, Kirkuk, Iraq \\ *Corresponding author \\ e-mail: mbayraktar@cu.edu.tr
}

(Received $9^{\text {th }}$ Apr 2021; accepted $10^{\text {th }}$ Jun 2021)

\begin{abstract}
SLC27A3 and $\beta$-Lactoglobulin are candidate genes that affect milk traits. This study aimed to determine the effect of polymorphisms of the SLC27A3 and $\beta$-Lactoglobulin genes on Hamdani sheep's milk components. The PCR-RFLP method was used to detect the SLC27A3 polymorphisms at exon 2, exon 3, and exon 4. The allele frequency of SNP1, SNP2 and SNP3 were 0.59(G), 0.41(T); 0.57(G), $0.43(\mathrm{C})$ and $0.58(\mathrm{~A})$ and $0.42(\mathrm{C})$ respectively. $\beta$-lactoglobulin allele frequency was $0.56(\mathrm{~A})$ and $0.44(\mathrm{~B})$. The statistical analysis showed an association between SLC27A3 and $\beta$-lactoglobulin polymorphisms and milk composition. The SLC27A3 and $\beta$-lactoglobulin polymorphisms can be used as a genetic marker to select milk component traits in sheep breeding programs.
\end{abstract}

Keywords: native breed, candidate gene, allele frequency, association analysis, SNP

\section{Introduction}

Milk is a complete diet; it contains essential nutrients that the body needs to perform vital functions. Many factors affect milk yield, the most important of which are genes and the environment (Aytekin and Boztepe, 2013; Giambra et al., 2014; Şahin et al., 2018). Milk is also the main ingredient for dairy products (Caja and Bocquier, 2000; Moatsou and Sakkas, 2019; Rachagani and Gupta, 2008). Cows occupy the first place in providing milk, but in countries that lack rich lands, sheep and goats remain essential sources of milk production (Kalyankar et al., 2016; Raynal-Ljutovac et al., 2008). Iraqi sheep belong to the fat-tailed Asian sheep and include three breeds; Karadi, Arabi and Awassi. Karadi sheep are white, while the head and shoulders are covered with black or dark brown wool (Al-Barzinji et al., 2011; Aziz and Oramary, 2005). Two distinct breeds are belonging to Karadi: immigrant, Al-Harkia and Al-Jaf, and a non-migratory breed, which is the Dzdia and Hamdani. The Hamdani sheep is one of the largest breeds in size, as the weight of the ram is about $85-90 \mathrm{~kg}$, and the ewe is $75-80 \mathrm{~kg}$. Its reproductive efficiency reaches $105 \%$ and produces milk and meat (Al-Barzinji and Othman, 2013; Alkass et al., 2021).

Increasing Hamdani sheep's productivity requires genetic improvement, such as determining candidate genes that affect milk traits. Many candidate genes affect production traits in sheep, among which are the SLC27A3 and $\beta$-lactoglobulin genes.

Fatty acid transport proteins (FATPs or SLC27A), also known as a solute carrier protein family 27 (SLC27), are transporter families, allowing the absorption of the fatty acid into the cells. This subfamily is part of the solute carrier protein family. This family contains six very homologous proteins highly conserved during evolution and expressed in all body tissues that use fatty acids (Doege and Stahl, 2006; Gimeno, 
2007; Houten and Wanders, 2010). The six FATPs are found in various tissues: FATP1 (SLC27A1): brown and white adipose tissue; FATP2 (SLC27A2): liver, kidney cortex; FATP3 (SLC27A3): fats, lungs; FATP4 (SLC27A4): liver, kidneys; FATP5 (SLC27A5): basal membrane of hepatocytes in the liver; FATP6 (SLC27A6): heart and skeletal muscle (Anderson and Stahl, 2013; Stahl, 2004; Stahl et al., 2001). SLC27A3 (Solute carrier family 27 member 3) encodes a protein involved in lipid metabolism. The increased expression of this gene in human neural stem cells derived from induced pluripotent stem cells suggests that it plays an essential role in early brain development (Hirschmugl et al., 2017; Pei et al., 2009; Sun et al., 2014). Ovine SLC27A3 gene located at chromosome 1, contains 10 exons and encodes 680 amino acids (Pecka-Kiełb et al., 2020). SLC27A3 gene is considered a candidate gene for milk traits in sheep (Pecka-Kiełb et al., 2020; Calvo et al., 2006; Kulig et al., 2010; Kowalewska-Łuczak et al., 2017). Casein constitute about $80 \%$ of milk proteins and consists of; $\alpha$ s 1-casein (CSN1S1), as2-casein (CSN1S2), $\beta$-casein (CSN2) and $\kappa^{-}$casein (CSN3). Whey proteins constitute about $20 \%$ of milk proteins and consist of; $\alpha$-lactalbumin, $\beta$-lactoglobulin, and other proteins (Čítek et al., 2019; Moioli et al., 2007). $\beta$-lactoglobulin is the major whey protein of sheep milk, and it is also present in many other mammalian species, but it is absent in human milk (Gras et al., 2016; Masala et al., 2019). $\beta$-lactoglobulin found it associated with milk yield, composition and cheese making. The molecular weight of $\beta$-lactoglobulin is $36.4 \mathrm{kDa}$ and consists of 162 amino acids (Elmaci et al., 2006; Triantaphyllopoulos et al., 2017). Ovine $\beta$ lactoglobulin located at chromosome 3 , and three different variants have been determined; $\mathrm{A}, \mathrm{B}$, and $\mathrm{C}$. In cattle, detected fifteen polymorphic variants of $\beta$ lactoglobulin gene out of which two variants A and B are most frequent (Elmaci et al., 2007; El-Shazly et al., 2012). The A variants (tyrosine) and B (histidine) differ at the amino acid position 20. An association has been described between $\beta$-lactoglobulin polymorphism and sheep milk composition (Othman et al., 2012; Rashaydeh et al., 2020).

This study explores to find the association between the SLC27A3 and $\beta$ lactoglobulin genes polymorphism and milk components in Hamdani sheep.

\section{Materials and methods}

\section{Experimental animals}

A total of 60 ewes of Hamdani sheep were used in the study. The ewes were three years old and taken from commercial farms in Kirkuk city/Iraq.

Milk samples were taken twice a month for three months. Ewes were fed on a ration consisting of $55 \%$ barley, $33 \%$ of wheat bran, $10 \%$ of soybean meal, $1 \%$ of salt, and $1 \%$ of lime, with two morning and evening meals at a rate of $500 \mathrm{gm} / \mathrm{head} /$ day with continuous water provision in addition to mineral salts, and hay was provided at a rate of $500 \mathrm{gm} / \mathrm{head} /$ day.

\section{Milk components analysis}

Milk components were measured twice a month for each ewe for three months. Milk samples were taken in the morning and the milk was placed in $60 \mathrm{~mm}$ plastic containers. Milk components (fat, protein, lactose, non-fat solids, and total solids) were analyzed by Milkotester Master Classic LM2. 


\section{Sample collection and DNA extraction}

Genetic analysis was carried out in the molecular genetics laboratory at the College of Veterinary, University of Kirkuk. The blood was collected from the jugular vein using tubes containing ethylenediamine tetra-acetic acid (EDTA) and stored at $-20{ }^{\circ} \mathrm{C}$. Genomic DNA was extracted from whole blood by using the phenol-chloroform methods. The primer sequence of the SLC27A3 gene locus was shown in Table 1. The PCR was done in a reaction volume of $20 \mu \mathrm{L}$, contains $5 \mu \mathrm{L}(50 \mathrm{ng}) \mathrm{DNA}, 5 \mu \mathrm{L}$ of PCR Master Mix (GoTaq ${ }^{\circledR}$ G2 Green Master Mix, Promega, USA), $0.5 \mu \mathrm{L}$ for each primer $(10 \mu \mathrm{mol})$ and $9 \mu \mathrm{L}$ distilled water.

Table 1. The primer sequences of SLC27A3 and $\beta$-lactoglobulin gene locus

\begin{tabular}{|c|c|c|c|c|c|c|}
\hline SNP & Position & Primer sequence & FL & RE & PCR conditions & Reference \\
\hline SNP1 & exon 2 & $\begin{array}{c}\text { 5'-GTAGAACTGCGGGGCTGTG-3' } \\
\text { 5'-AGGAGGTCATAGTTCCTGTTCC-3' }\end{array}$ & $319 \mathrm{bp}$ & $\begin{array}{c}\text { Hpy } 188 \\
\text { III }\end{array}$ & $\begin{array}{c}94^{\circ} \mathrm{C} 5 \mathrm{~m}, \\
94^{\circ} \mathrm{C} 30 \mathrm{~s}, \\
53^{\circ} \mathrm{C} 45 \mathrm{~s}, \\
72^{\circ} \mathrm{C} 45 \mathrm{~s}, \\
30 \mathrm{cycles} \\
72^{\circ} \mathrm{C} 5 \mathrm{~m}\end{array}$ & \multirow{3}{*}{$\begin{array}{l}\text { Pecka-Kiełb } \\
\text { et al. (2020) }\end{array}$} \\
\hline SNP2 & exon 3 & $\begin{array}{l}\text { 5'-GAGACAAGGCTTGGGTTCAG-3' } \\
\text { 5'-AGCCTCCTTCCTCTCCATTC-3' }\end{array}$ & $354 \mathrm{bp}$ & ScrFI & $\begin{array}{c}94^{\circ} \mathrm{C} 5 \mathrm{~m}, \\
94^{\circ} \mathrm{C} 30 \mathrm{~s}, \\
53^{\circ} \mathrm{C} 45 \mathrm{~s}, \\
72^{\circ} \mathrm{C} 45 \mathrm{~s}, \\
30 \text { cycles } \\
72^{\circ} \mathrm{C} 5 \mathrm{~m}\end{array}$ & \\
\hline SNP3 & exon 4 & $\begin{array}{l}\text { 5'-TCTGGGAAGAAGGGAGTCAG-3' } \\
\text { 5'-TCTCCCССTTCCATTTTCTT-3' }\end{array}$ & $337 \mathrm{bp}$ & Fnu4HI & $\begin{array}{c}94{ }^{\circ} \mathrm{C} 5 \mathrm{~m}, \\
94{ }^{\circ} \mathrm{C} 30 \mathrm{~s}, \\
50{ }^{\circ} \mathrm{C} 45 \mathrm{~s}, \\
72{ }^{\circ} \mathrm{C} 45 \mathrm{~s}, \\
30 \text { cycles } \\
72^{\circ} \mathrm{C} 5 \mathrm{~m}\end{array}$ & \\
\hline$\beta$-lactoglobulin & exon 2 & $\begin{array}{l}\text { 5'-CAACTCAAGGTCCCTCTCCA-3' } \\
\text { 5'-CTTCAGCTCCTCCACGTACA-3', }\end{array}$ & $120 \mathrm{bp}$ & RsaI & $\begin{array}{c}94^{\circ} \mathrm{C} 5 \mathrm{~m}, \\
95^{\circ} \mathrm{C} 15 \mathrm{~s}, \\
60^{\circ} \mathrm{C} 30 \mathrm{~s}, \\
72^{\circ} \mathrm{C} 1 \mathrm{~m}, \\
36 \text { cycles } \\
72^{\circ} \mathrm{C} 10 \mathrm{~m}\end{array}$ & $\begin{array}{l}\text { Feligini et al. } \\
\quad(1998)\end{array}$ \\
\hline
\end{tabular}

FL: fragment length

\section{PCR-RFLP method}

The mix consisted of $10 \mu \mathrm{L}$ PCR product, $4 \mu \mathrm{L}$ distilled water, $2 \mu \mathrm{L} 10 \mathrm{X}$ buffer and $1 \mu \mathrm{L} / \mathrm{U}$ restriction enzyme (Total of $17 \mu \mathrm{L}$ ). Digestion products were separated at $3 \%$ agarose gel in $80 \mathrm{~V}$ for $60 \mathrm{~min}$. The gel stained by ethidium bromide. The results were checked under ultraviolet lights.

\section{Statistical analysis}

The allele and genotype frequency of the genes and the Chi-square test $\chi^{2}$ were calculated by popgen32 (ver.1.32). Association analyses were done by using the General Linear Model (GLM) of Minitab 16. The least-squares means were compared using Tukey, the least significant difference test.

The general linear model was:

$$
Y i j=\mu+\alpha i+e i j
$$


where: Yij: traits measured, $\mu$ : overall mean for each trait, $\alpha \mathrm{i}$ : genotypes effect, eij: random error.

\section{Results}

\section{SNP1 locus polymorphism}

$319 \mathrm{bp}$ of PCR product was amplified. Three genotypes (GG, GT and TT) were obtained. GG genotype was 319 bp; GT genotype was 319, 194 and 125 bp; TT genotype was 194 and 125 bp (Fig. 1). Chi-square $\chi^{2}$ test showed agreement to HardyWeinberg equilibrium $(\mathrm{p}>0.05)$ (Table 2). The allele and genotype frequency was $0.59(\mathrm{G})$ and $0.41(\mathrm{~T}) ; 0.38(\mathrm{GG}), 0.42(\mathrm{GT})$ and $0.20(\mathrm{TT})$.

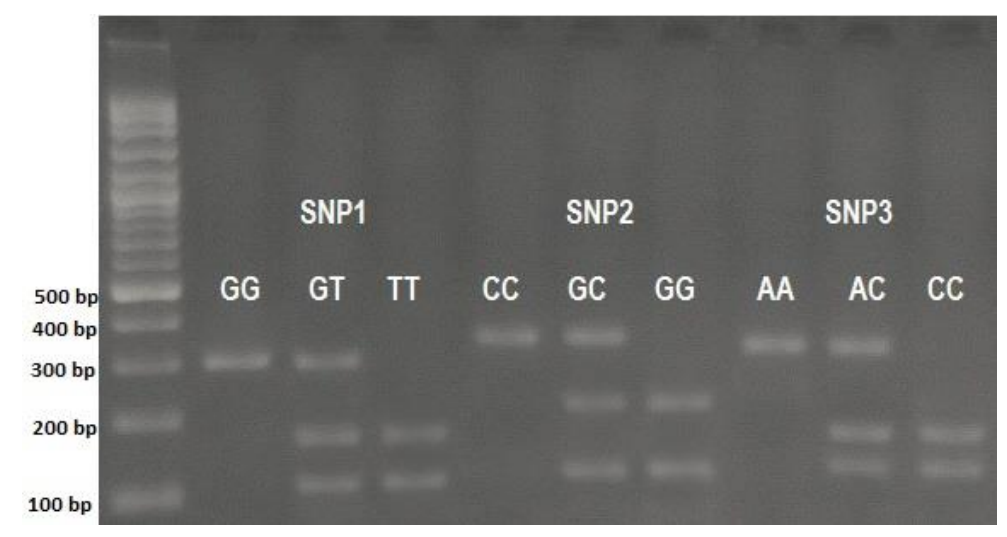

Figure 1. PCR-RFLP band patterns of the SLC27A3 gene

Table 2. Genotype and allele frequency of the SLC27A3 and $\beta$-lactoglobulin genes

\begin{tabular}{|c|c|c|c|}
\hline Polymorphism & Genotype frequencies & Allele frequencies & $\chi^{2}$ \\
\hline SNP1 & $\begin{array}{l}0.38(\mathrm{GG}) \\
0.42 \text { (GT) } \\
0.20(\mathrm{TT})\end{array}$ & $\begin{array}{l}0.59(\mathrm{G}) \\
0.41(\mathrm{~T})\end{array}$ & 1.13 \\
\hline SNP2 & $\begin{array}{l}0.36 \text { (GG) } \\
0.42 \text { (GC) } \\
0.22(\mathrm{CC}) \\
\end{array}$ & $\begin{array}{l}0.57(\mathrm{G}) \\
0.43(\mathrm{C})\end{array}$ & 1.30 \\
\hline SNP3 & $\begin{array}{l}0.36(\mathrm{AA}) \\
0.43(\mathrm{AC}) \\
0.20(\mathrm{CC})\end{array}$ & $\begin{array}{l}0.58(\mathrm{~A}) \\
0.42(\mathrm{C})\end{array}$ & 0.70 \\
\hline$\beta$-lactoglobulin & $\begin{array}{l}0.28(\mathrm{AA}) \\
0.55(\mathrm{AB}) \\
0.17(\mathrm{BB})\end{array}$ & $\begin{array}{l}0.56(\mathrm{~A}) \\
0.44(\mathrm{~B})\end{array}$ & 0.79 \\
\hline
\end{tabular}

\section{SNP2 locus polymorphism}

$354 \mathrm{bp}$ of PCR product was amplified. Three genotypes (GG, GC and CC) were obtained. GG genotype was 222 and 132 bp; GC genotype was 354, 222 and 132 bp; CC genotype was 354 bp (Fig. 1). Chi-square $\chi^{2}$ test showed agreement to HardyWeinberg equilibrium $(\mathrm{p}>0.05)$ (Table 2$)$. The allele and genotype frequency was $0.57(\mathrm{G})$ and $0.43(\mathrm{C}) ; 0.36(\mathrm{GG}), 0.42(\mathrm{GC})$ and $0.22(\mathrm{CC})$. 


\section{SNP3 locus polymorphism}

$337 \mathrm{bp}$ of PCR product was amplified. Three genotypes (AA, AC and CC) were obtained. AA genotype was $337 \mathrm{bp}$; AC genotype was 337, 190 and $147 \mathrm{bp}$; CC genotype was 190 and $147 \mathrm{bp}$ (Fig. 1). Chi-square $\chi^{2}$ test showed agreement to HardyWeinberg equilibrium $(\mathrm{p}>0.05)$ (Table 2). The allele and genotype frequency was $0.58(\mathrm{~A})$ and $0.42(\mathrm{C}) ; 0.36(\mathrm{AA}), 0.43(\mathrm{AC})$ and $0.20(\mathrm{CC})$.

\section{ß-Lactoglobulin locus polymorphism}

$120 \mathrm{bp}$ of PCR product was amplified. Three genotypes (AA, AB and $\mathrm{BB}$ ) were determined. AA genotype was 66, 37 and $17 \mathrm{bp}$; AB genotype was 103, 66, 37 and 17 bp; BB genotype was 103 and 17 bp (Fig. 2). Chi-square $\chi^{2}$ test showed agreement to Hardy-Weinberg equilibrium $(\mathrm{p}>0.05)$ (Table 2$)$. The allele and genotype frequency was $0.56(\mathrm{~A})$ and $0.44(\mathrm{~B}) ; 0.28(\mathrm{AA}), 0.55(\mathrm{AB})$ and $0.17(\mathrm{BB})$.

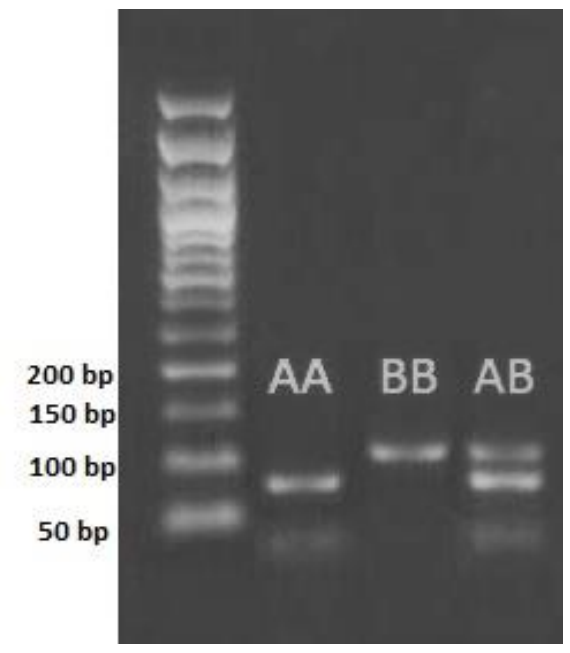

Figure 2. PCR-RFLP band patterns of the $\beta$-lactoglobulin gene

\section{Discussion}

In this study, three genotypes were identified of SNP1, SNP2 and SNP3. The allele frequency was $0.59(\mathrm{G}), 0.41(\mathrm{~T})$ of SNP1, 0.57(G), 0.43(C) of SNP2 and 0.58(A), 0.42(C) of SNP3. Also, Pecka-Kiełb et al. (2020) showed allele frequency in Zosl achtena valaska sheep for SNP1, SNP2 and SNP3 as 0.53(G), 0.47(T); 0.53(G), $0.47(\mathrm{C})$; $0.55(\mathrm{~A}), 0.45(\mathrm{C})$ respectively. The results show a similarity with a slight increase of allele frequency in Hamdani sheep. The association results showed that there were significant association between the SLC27A3 gene polymorphisms and fat, protein and total solids $(\mathrm{p}<0.05)$ (Table 3). The SNP1 polymorphisms were associated with fat, protein and total solids. SNP2 polymorphism showed an association only with protein. Whereas the SNP3 did not show any association between the polymorphism and milk composition. Also, Pecka-Kiełb et al. (2020) did not find any association between SNP2 and milk composition. The TT genotypes of SNP1 showed the lowest fat content $(4.466 \pm 0.158)$ compared to other genotypes.

Pecka-Kiełb et al. (2020) found influence of the SLC27A3 gene polymorphisms on the fat, lactose and dry matter content in sheep milk. Calvo et al. (2006) determined SLC27A3 as candidate genes for fat content in sheep milk. 
Table 3. Association analysis between SLC27A3 gene locus and milk composition

\begin{tabular}{|c|c|c|c|c|}
\hline \multirow{3}{*}{ Traits } & \multicolumn{3}{|c|}{ Genotypes (mean \pm standard error) } & \multirow{3}{*}{ p-value } \\
\hline & \multicolumn{3}{|c|}{ SNP1 } & \\
\hline & GG & GT & TT & \\
\hline Fat $\%$ & $4.890 \pm 0.112^{\mathrm{ab}}$ & $5.028 \pm 0.107^{\mathrm{a}}$ & $4.466 \pm 0.158^{b}$ & 0.014 \\
\hline Protein $\%$ & $6.584 \pm 0.029^{\mathrm{ab}}$ & $6.570 \pm 0.028^{b}$ & $6.695 \pm 0.041^{\mathrm{a}}$ & 0.037 \\
\hline Lactose $\%$ & $4.458 \pm 0.034$ & $4.372 \pm 0.032$ & $4.395 \pm 0.048$ & 0.195 \\
\hline Non-fat solids $\%$ & $11.79 \pm 0.118$ & $11.89 \pm 0.112$ & $11.85 \pm 0.166$ & 0.826 \\
\hline \multirow[t]{3}{*}{ Total solids $\%$} & $15.46 \pm 0.045^{\mathrm{a}}$ & $15.32 \pm 0.043^{\mathrm{ab}}$ & $15.24 \pm 0.063^{\mathrm{b}}$ & 0.016 \\
\hline & \multicolumn{3}{|c|}{ SNP2 } & \\
\hline & GG & GC & $\mathrm{CC}$ & \\
\hline Fat $\%$ & $4.706 \pm 0.120$ & $4.709 \pm 0.113$ & $4.969 \pm 0.140$ & 0.296 \\
\hline Protein $\%$ & $6.687 \pm 0.031^{\mathrm{a}}$ & $6.599 \pm 0.029^{\mathrm{ab}}$ & $6.564 \pm 0.036^{\mathrm{b}}$ & 0.029 \\
\hline Lactose $\%$ & $4.353 \pm 0.036$ & $4.460 \pm 0.034$ & $4.412 \pm 0.042$ & 0.681 \\
\hline Non-fat solids $\%$ & $11.73 \pm 0.126$ & $12.04 \pm 0.118$ & $11.75 \pm 0.147$ & 0.118 \\
\hline \multirow[t]{3}{*}{ Total solids \% } & $15.33 \pm 0.048$ & $15.35 \pm 0.045$ & $15.34 \pm 0.056$ & 0.942 \\
\hline & \multicolumn{3}{|c|}{ SNP3 } & \\
\hline & $\mathbf{A A}$ & $\mathbf{A C}$ & $\mathrm{CC}$ & \\
\hline Fat $\%$ & $5.017 \pm 0.116$ & $4.665 \pm 0.107$ & $4.703 \pm 0.130$ & 0.066 \\
\hline Protein $\%$ & $6.647 \pm 0.030$ & $6.613 \pm 0.028$ & $6.590 \pm 0.034$ & 0.445 \\
\hline Lactose $\%$ & $4.394 \pm 0.035$ & $4.398 \pm 0.032$ & $4.434 \pm 0.039$ & 0.681 \\
\hline Non-fat solids $\%$ & $11.92 \pm 0.121$ & $11.79 \pm 0.112$ & $11.81 \pm 0.137$ & 0.706 \\
\hline \multirow[t]{3}{*}{ Total solids \% } & $15.29 \pm 0.046$ & $15.36 \pm 0.043$ & $15.37 \pm 0.052$ & 0.434 \\
\hline & \multicolumn{3}{|c|}{$\beta$-Lactoglobulin } & \\
\hline & $\mathbf{A A}$ & $\mathbf{A B}$ & BB & \\
\hline Fat $\%$ & $4.759 \pm 0.104^{\mathrm{ab}}$ & $5.047 \pm 0.117^{\mathrm{a}}$ & $4.578 \pm 0.152^{b}$ & 0.040 \\
\hline Protein $\%$ & $6.606 \pm 0.027$ & $6.678 \pm 0.030$ & $6.566 \pm 0.040$ & 0.065 \\
\hline Lactose $\%$ & $4.349 \pm 0.031^{\mathrm{b}}$ & $4.374 \pm 0.035^{\mathrm{ab}}$ & $4.502 \pm 0.046^{\mathrm{a}}$ & 0.021 \\
\hline Non-fat solids $\%$ & $11.82 \pm 0.110$ & $12.01 \pm 0.123$ & $11.70 \pm 0.159$ & 0.267 \\
\hline Total solids \% & $15.38 \pm 0.042$ & $15.31 \pm 0.047$ & $15.34 \pm 0.061$ & 0.555 \\
\hline
\end{tabular}

${ }^{\mathrm{a}, \mathrm{b}}$ There are significant differences $(\mathrm{p}<0.05)$

The allele frequency of $\beta$-lactoglobulin was $0.56(\mathrm{~A})$ and $0.44(\mathrm{~B})$. Various studies showed that the A allele frequency is usually higher than the $\mathrm{B}$ allele. The A allele frequencies were; 0.78 in the Karacabey Merino sheep (Elmaci et al., 2007); 0.68 in the Teleorman Black Head sheep (Gras et al., 2016); 0.58 in the Karagouniko sheep (Triantaphyllopoulos et al., 2017); 0.78, 0.76 and 0.98 in the Kıvırcık, Gökçeada and Sakız respectively (Elmaci et al., 2006); 0.55 in Pramenka breed (Rustempašić et al., 2018); 0.71 in Karakul (Kevorkian et al., 2008). However, in some studies, the B allele frequency was higher than A allele frequency: 0.53 in Kivircık (Gürcan et al., 2018); 0.52 in Dubska Pramenka (Masala et al., 2019); 0.52 in Awassi (Dakheel et al., 2021). 
The statistical analysis showed the influence of $\beta$-lactoglobulin gene polymorphisms on fat and lactose content. The BB genotypes showed higher lactose content $(4.578 \pm 0.152)$ compared to other genotypes.

The A variant of $\beta$-lactoglobulin is associated with protein, fat casein content, and total solids. Whereas, B allele is associated with higher milk yield. The AA genotype is more efficient for cheese manufacturing than other genotypes AB and BB (Amigo et al., 2000). Significant associations were determined between $\beta$-lactoglobulin gene polymorphisms and protein, fat, lactose, and solids non-fat in Awassi and Morkaraman sheep breeds (Çelik and Özdemir, 2007). No association was identified between $\beta$ lactoglobulin variants and milk components in sheep Noami, Sawakni, Harry and Nagdi (El-Shazly et al., 2012). Gras et al. (2016) found association between $\beta$-lactoglobulin and milk yield and composition. Triantaphyllopoulos et al. (2017) determined significant effects of $\beta$-lactoglobulin polymorphism on lactose percentage and somatic cell count (SCC). The BB genotype of the $\beta$-lactoglobulin gene showed the highest fat, protein, solids non-fat, lactose, and density compared to other AA and BB (Jawasreh et al., 2019). The effect of the $\beta$-lactoglobulin gene was determined on fat content and density in Awassi sheep (Rashaydeh et al., 2020). BB genotype showed highest milk yield (Dakheel et al., 2021).

\section{Conclusions}

The Hamdani breeds shown genetic polymorphisms of SLC27A3 and $\beta$ lactoglobulin gene locus. The results showed the effect of the SLC27A3 gene locus on protein, fat and total solids. Also, the $\beta$-lactoglobulin gene locus shown a significant association with fat and lactose. Therefore, these genes can be used as genetic markers to improve milk traits in Hamdani sheep. However, the frequency of these genes must also be increased by following appropriate breeding programs in Hamdani sheep.

\section{REFERENCES}

[1] Aytekin, I., Boztepe, S. (2013): Associations of Pit-1 gene polymorphism with milk yield and composition traits in brown Swiss cattle. - Journal of Animal and Plant Sciences 23(5): 1281-1289.

[2] Giambra, I., Brandt, H., Erhardt, G. (2014): Milk protein variants are highly associated with milk performance traits in East Friesian Dairy and Lacaune sheep. - Small Ruminant Research 121(2-3): 382-394.

[3] Şahin, Ö., Boztepe, S., Aytekin, İ. (2018): A1 and A2 bovine milk, the risk of Betacasomorphin-7 and its possible effects on human health: (II) possible effects of betacasomorphin-7 on human health. - Selcuk Journal of Agriculture and Food Sciences 32(3): 640-645.

[4] Caja, G., Bocquier, F. (2000): Effects of nutrition on the composition of sheep's milk. Cahiers Options Méditerranéennes 52(59-74).

[5] Moatsou, G., Sakkas, L. (2019): Sheep milk components: focus on nutritional advantages and biofunctional potential. - Small Ruminant Research 180(86-99).

[6] Rachagani, S., Gupta, I. D. (2008): Bovine kappa-casein gene polymorphism and its association with milk production traits. - Genetics and Molecular Biology 31(4): 893897. 
[7] Kalyankar, C. D., Sarode, A. R., Khedkar, C. D., Deosarkar, S. S., Pawshe, R. D. (2016): Sheep: Milk. - In: Caballero, B. et al. (eds.) Encyclopedia of Food and Health. Elsevier, London, pp. 758-763.

[8] Raynal-Ljutovac, K., Lagriffoul, G., Paccard, P., Guillet, I., Chilliard, Y. (2008): Composition of goat and sheep milk products: an update. - Small Ruminant Research 79(1): 57-72.

[9] Al-Barzinji, Y., Lababidi, S., Rischkowsky, B., Al-Rawi, A., Tibbo, M., Hassen, H., Baum, M. (2011): Assessing genetic diversity of Hamdani sheep breed in Kurdistan region of Iraq using microsatellite markers. - African Journal of Biotechnology 10(67): 15109-15116.

[10] Aziz, K., Oramary, R. (2005): A study on fleece characterization of Hamadani sheep in Erbil plain. - Mesopotamia Journal of Agriculture 33(1): 3-12.

[11] Al-Barzinji, Y. M., Othman, G. U. (2013): Genetic polymorphism in FecB gene in Iraqi sheep breeds using RFLP-PCR technique. - Journal of Agriculture and Veterinary Science 2(4): 46-48.

[12] Alkass, J. E., Hermiz, H. N., Baper, M. I. (2021): Some aspects of reproductive efficiency in awassi ewes: A review. - Iraqi Journal of Agricultural Sciences 52(1): 20-27.

[13] Doege, H., Stahl, A. (2006): Protein-mediated fatty acid uptake: novel insights from in vivo models. - Physiology 21(4): 259-268.

[14] Gimeno, R. E. (2007): Fatty acid transport proteins. - Current Opinion in Lipidology 18(3): 271-276.

[15] Houten, S. M., Wanders, R. J. (2010): A general introduction to the biochemistry of mitochondrial fatty acid $\beta$-oxidation. - Journal of Inherited Metabolic Disease 33(5): 469477.

[16] Anderson, C. M., Stahl, A. (2013): SLC27 fatty acid transport proteins. - Molecular Aspects of Medicine 34(2-3): 516-528.

[17] Stahl, A. (2004): A current review of fatty acid transport proteins (SLC27). - Pflügers Archiv 447(5): 722-727.

[18] Stahl, A., Gimeno, R. E., Tartaglia, L. A., Lodish, H. F. (2001): Fatty acid transport proteins: a current view of a growing family. - Trends in Endocrinology \& Metabolism 12(6): 266-273.

[19] Hirschmugl, B., Desoye, G., Catalano, P., Klymiuk, I., Scharnagl, H., Payr, S., Kitzinger, E., Schliefsteiner, C., Lang, U., Wadsack, C. (2017): Maternal obesity modulates intracellular lipid turnover in the human term placenta. - International Journal of Obesity 41(2): 317-323.

[20] Pei, Z., Sun, P., Huang, P., Lal, B., Laterra, J., Watkins, P. A. (2009): Acyl-CoA synthetase VL3 knockdown inhibits human glioma cell proliferation and tumorigenicity. - Cancer Research 69(24): 9175-9182.

[21] Sun, P., Xia, S., Lal, B., Shi, X., Yang, K. S., Watkins, P. A., Laterra, J. (2014): Lipid metabolism enzyme ACSVL3 supports glioblastoma stem cell maintenance and tumorigenicity. - BMC Cancer 14(1): 1-11.

[22] Pecka-Kiełb, E., Kowalewska-Łuczak, I., Czerniawska-Piątkowska, E., Zielak-Steciwko, A. E. (2020): Effects of Single Nucleotide Polymorphisms in the SLC27A3 Gene on the Nutritional Value of Sheep Milk. - Animals 10(4): 562.

[23] Calvo, J., Martínez-Royo, A., Beattie, A., Dodds, K., Marcos-Carcavilla, A., Serrano, M. (2006): Fine mapping of genes on sheep chromosome 1 and their association with milk traits. - Animal Genetics 37(3): 205-210.

[24] Kulig, H., Kowalewska-Łuczak, I., Kmieć, M., Wojdak-Maksymiec, K. (2010): ANXA9, SLC27A3, FABP3 and FABP4 single nucleotide polymorphisms in relation to milk production traits in Jersey cows. - Czech J. Anim. Sci 55(11): 463-467.

[25] Kowalewska-Łuczak, I., Czerniawska-Piątkowska, E., Pecka-Kiełb, E. (2017): Investigation on relationships of the FABP3 and SLC27A3 genes with milk production traits in sheep. - J Elem 22(4): 1485-1493. 
[26] Čítek, J., Hanusová, L., Lískovcová, L., Samková, E., Hanuš, O., Hasoňová, L., Kř́žová, Z., Večerek, L. (2019): Polymorphisms in CSN3, CSN2 and LGB genes and their relation to milk production in dairy cattle in the Czech Republic. - Acta Universitatis Agriculturae et Silviculturae Mendelianae Brunensis 67(1): 19-24.

[27] Moioli, B., D'Andrea, M., Pilla, F. (2007): Candidate genes affecting sheep and goat milk quality. - Small Ruminant Research 68(1-2): 179-192.

[28] Gras, M., Pistol, G., Pelmus, R., Lazar, C., Grosu, H., Ghita, E. (2016): Relationship between gene polymorphism and milk production traits in Teleorman Black Head sheep breed. - Revista MVZ Córdoba 21(1): 5124-5136.

[29] Masala, A., Alilović, I., Ohran, H., Kusza, S., Goletic, T., Hrkovic-Porobija, A., Hodzic, A. (2019): Genetic Polymorphism $\beta$-Lactoglobulin Gene in Dubska Pramenka Sheep Breed. - In: Badnjevic, R. S., Pokvic, L. G. (eds.) Proceedings of the International Conference on Medical and Biological Engineering, 16-18 May 2019, Banja Luka, Bosnia and Herzegovina. Springer, Switzerland, pp. 641-645.

[30] Elmaci, C., Oner, Y., Balcioglu, M. S. (2006): Genetic polymorphism of $\beta$-lactoglobulin gene in native Turkish sheep breeds. - Biochemical Genetics 44(7-8): 376-381.

[31] Triantaphyllopoulos, K. A., Koutsouli, P., Kandris, A., Papachristou, D., Markopoulou, K. E., Mataragka, A., Massouras, T., Bizelis, I. (2017): Effect of $\beta$-lactoglobulin gene polymorphism, lactation stage and breed on milk traits in Chios and Karagouniko sheep breeds. - Annals of Animal Science 17(2): 371-384.

[32] Elmaci, C., Oner, Y., Balcioglu, M. (2007): $\beta$-lactoglobulin gene types in Karacabey Merino sheep breeds using PCR-RFLP. - Journal of Applied Animal Research 32(2): 145-148.

[33] El-Shazly, S. A., Mahfouz, M. E., Al-Otaibi, S. A., Ahmed, M. M. (2012): Genetic polymorphism in [beta]-lactoglobulin gene of some sheep breeds in the Kingdom of Saudi Arabia (KSA) and its influence on milk composition. - African Journal of Biotechnology 11(19): 4330.

[34] Othman, O. E., El-Fiky, S. A., Hassan, N. A., Mahfouz, E. R., Balabel, E. A. (2012): Genetic polymorphism of whey protein genes $\beta$-LG and $\alpha$-LA in three Egyptian sheep breeds. - Journal of Applied Biological Sciences 6(3): 25-30.

[35] Rashaydeh, F., Sholi, N., Al-Atiyat, R. (2020): Genetic polymorphisms of milk genes ( $\beta$ lactoglobulin and $\kappa$-casein) in indigenous Awassi and improved Awassi sheep of Palestine. - Livestock Research for Rural Development 32(5).

[36] Rustempašić, A., Dokso, A., Zečević, E., Hodžić, A., Hrković-Porobija, A., Sarić, Z., Miskoska-Milevska, E., Popovski, Z., Brka, M. (2018): Polymorphism of $\beta$-lactoglobulin in Pramenka sheep breed in Bosnia and Herzegovina. - Journal of Animal \& Plant Sciences 28(1): 337-340.

[37] Kevorkian, S., Manea, M. A., Georgescu, S., Dinischiotu, A., Costache, M. (2008): Genotyping of $\beta$-lactoglobulin gene in Karakul sheep breed. - Scientific Papers Animal Science and Biotechnologies 41(1): 112-116.

[38] Gürcan, E. K., Çobanoğlu, Ö., Almaz, E. (2018): Determination of betalactoglobulin gene polymorphism in Kivircik sheep. - Black Sea Journal of Engineering and Science 1(1): 13-17.

[39] Masala, A., Alilović, I., Ohran, H., Kusza, S., Goletic, T., Hrkovic-Porobija, A., Hodzic, A. (2019): Genetic Polymorphism $\beta$-Lactoglobulin Gene in Dubska Pramenka Sheep Breed. - In Badnjevic, R. S., Pokvic, L. G. (eds.) Proceedings of the International Conference on Medical and Biological Engineering, 16-18 May 2019, Banja Luka, Bosnia and Herzegovina. Springer, Switzerland, pp. 641-645.

[40] Dakheel, M. H., Fadhil, I. A., T. Q. Al-Sarai (2021): Polymorphism of $\beta$-lactoglobulin gene and its effect on selection program in Awassi sheep. - Indian Journal of Ecology 13(48): 58-61. 
[41] Amigo, L., Recio, I., Ramos, M. (2000): Genetic polymorphism of ovine milk proteins: its influence on technological properties of milk - a review. - International Dairy Journal 10(3): 135-149.

[42] Çelik, Ş., Özdemir, S. (2007): beta-Lactoglobulin variants in Awassi and Morkaraman sheep and their association with the composition and rennet clotting time of the milk. Turkish Journal of Veterinary and Animal Sciences 30(6): 539-544.

[43] Jawasreh, K., Amareen, A. A., Aad, P. (2019): Effect and interaction of $\beta$-Lactoglobulin, Kappa Casein, and Prolactin genes on milk production and composition of Awassi sheep. - Animals 9(382): 1-14.

[44] Rashaydeh, F., Sholi, N., Al-Atiyat, R. (2020): Genetic polymorphisms of milk genes ( $\beta$ lactoglobulin and $\kappa$-casein) in indigenous Awassi and improved Awassi sheep of Palestine. - Livestock Research for Rural Development 32(5): 1-10. 